\title{
Explicit and implied significance of contemporary public spaces. Part 1. Spaces of attractions
}

\author{
Dariusz Dziubiński \\ Faculty of Architecture; Wroctaw University of Technology \\ Prusa 53/55, 50-317 Wroctaw, Poland \\ dariusz.dziubinski@pwr.edu.pl (D) 0000-0003-1294-3623
}

„We live in a place that knows only the price of bricks and has forgotten the people who give them value." [1]

\begin{abstract}
This text presents considerations encouraged by thoughts and conclusions gained from research on several beach bars and their comparison with other urban public spaces, run in Wrocław from 2018 to 2019. The similarities and differences between the two types of spaces provoke a question about the meaning of what we call ,public spaces” today. The question is also asked, somewhat perversely, about the validity of following best practices based on proxemic principles and focused on attracting and retaining people in urban spaces. The paper examines not so much the rules but the purpose, in other words the type of space we receive/can achieve as a result of applying these principles, since people in the urban space (private or public) are only guests, while their choice is reduced to the top-down offer. The above doubt also results from the conclusion regarding the most important feature determining attractiveness of a beach bar space, which in my opinion, is the freedom of behaviour for users. In it we can see deficiencies of the prevailing narrative about our participation in space and, above all, the possibility of choice, or what should be called the limitations of choice - the lack of possession/self-agency. Such a situation, largely conditioned by politics (and economics), reduces public space to the role of a "space of attractions" (curiosities), whose action and participation is based on experiencing - on a direct experience. The clash of these two forces - standardization and individualization, erodes the current model of common spaces based on the historical (nineteenth century) one, whose images are transferred only in the form of empty clichés. Thus, the limitation of choices, the need to fall into line and appearances of a community lead to an escape upwards - enclaves for the chosen ones (omnitopia) and downwards - niches for the rebellious ones (heterotopia), while beach bars represent both ways of escape. Against this background, the purposefulness of expert/ top-down creation of public spaces, carried out in isolation from other essential values and laws, appears problematic.
\end{abstract}

Keywords: public space, proxemics, have-nothing, matching, giving up 


\section{Introduction}

In 2018 I carried out observations in several beach bars which have been established within recent years in Wrocław. In my research, I assessed the quality of these public spaces and on this basis, I compared them with urban public spaces, which I have been investigating since $2004^{1}$.

Beach bars are a new feature, they are very popular and arouse astonishment ${ }^{2}$. Their good-looking, inviting and lively space that attracts people is a mirror for other urban spaces. Its reflection perfectly shows advantages and disadvantages of both types of space. The research extracted undoubted advantages of beach bars which are imitation-worthy and led to conclusions about similarity of both types of spaces including their operation, as well as about inadequate differentiation of public spaces based on the type of ownership. Public or private, they all impose specific roles on users, leaving small margin for interaction, which in my opinion is a more important issue ${ }^{3}$.

This article is an attempt to refer to the role that urban spaces play or rather could/should play for city's communities ${ }^{4}$ in today's reality. The considerations challenge the meaning and sense of these spaces and tasks they are to fulfill, even if it were "to break the already open door down". The basic goal is to find and confirm what determines the power of attraction (attractiveness), what is beneficial, but at the same time what is unfavourable and dangerous, what drives people to be together and what hinders it. Therefore, the intermediate goal is to look at the meaning of the word "public" and examine its contemporary significance, with the intention to seek the possibility of what is unifying - what allows and what disturbs us to think of society as a community and a space as a common space ${ }^{5}$.

This paper specifically strives to pose questions which lead to explaining not only the reason why people come to public spaces and stay there together and what they gain from it, but especially to show what they do not find/ do not get there. Hence, it is to question the meaning of the so-called "public spaces". The idea was to show what is the true character and role of top-down public spaces and the reason for giving them up in the favour of other (different) choices. Reflections on processes that take place in public spaces allow to indicate what kind of opportunities and (maybe especially) threats they create. The nature of considerations based on questioning imposes an open form. It allows to read public spaces in relation

1 The basis for observation and evaluation of the examined spaces was the Place Diagram proposed by the Project for Public Space (PPS Inc.), which is a framework for evaluation of the "effectiveness" of a given space - it allows to understand how it works [2, p.92].

2 Such astonishment is characteristic of ethnological (anthropological) observation, where everyday life, ordinary objects are taken, are perceived as something worthy of attention despite their "ordinariness" - they are ,exotic" for researchers. Beach bars have their exotic connotations due to their place of origin, but also locally, in our conditions, they are not (at least at the beginning) ordinary. The „exotification” which was formerly colloquial, so obvious and therefore not deserving of attention, can be found in the works of researchers such as RochSulima [3, p.9], Wojciech J. Burszta [4, p.13].

3 As Stavros Stavrides noted, public spaces, as opposed to common spaces, "have always been subordinate to and connected to some governing body that allowed their use", were (...) described as spaces managed, supervised and controlled by anybody that regulates their use". [5, p.17].

4 The role of public space, its function, assignment, mission, vocation, position, purpose, participation, task, meaning are analysed by many authors, e.g. Krzysztof Bierwiaczonek [6]. These issues were also collected in the Charter of Public Space adopted by the III Congress of Polish Urbanism [7].

5 Common space, as Stavros Stavrides explains, is something more than public space, because „,...) it is created on the basis of a common language as an area of negotiation" [8, p.54]. 
to the actual possibility of using them in a broad context (implied meaning), not only from the position of the most prevalent, pragmatic and expert approach referring to the proximic principles $^{6}$ (explicit meaning).

The study is a qualitative research, similar to research in social sciences (understanding cultural phenomena), which applies intuitive (formulating assumptions) and inductive methods (drawing conclusions). It is to describe the nature of the studied phenomenon involving public spaces in a specific moment in which they currently are. It is a general and abstract comparison that refers to the wide current in culture. The methodology is based on both observations and conclusions from the city space analysis included in previous studies and available knowledge concerning the broadly understood subject. For the sake of argument fluency, references to literature are placed only in footnotes.

The text does not formulate closed answers and solutions. I used questions and polemics as a cognitive method, while its important element is to show the doubts that undermine the commonly accepted "certainty". Considerations carried out in the spirit of epoché touch upon what is not fully verifiable and assume putting aside the accepted and used ways of thinking. The paper draws attention to certain disturbing phenomena and processes that take place today in public spaces, and which visibly jeopardise their operation. In particular, it addresses the issue of offering the users the possibility of fully-fledged participation in the space. Although the problem refers to all cities, it is more apparent in more (semi-)provincial ones. Wrocław is only a reference point in the article due to the location of previous studies.

\section{Questions / doubts}

Space itself can be attractive by focusing on its scenic values, while an effective and encouraging filling (function, equipment, furniture) increases its value and gives reason to emerge, stop there and/or stay longer to meet and be with others ${ }^{8}$. The meeting serves as an opportunity to exchange - pass on goods, money, ideas, knowledge and information to each other. Above all, however, by interacting with others, people give each other less tangible "gifts", such as intimacy, acceptance and tenderness. Interdependence between the quality of space and possibilities and intensity of human and social interaction results directly from our psychological and anthropological (also sociological) conditions ${ }^{10}$, the knowledge of which is crucial for success - a social success of a space. This pragmatic, proxemic ${ }^{11}$ approach, developed since late 1960s, has led to

6 Research on proximal principles initiated by Edward T. Hall is largely based on cultural conditions (social distances in space, or the influence of the shape of space/equipment on feelings). In his books The Silent Language [9] Hidden Differences [10] the various ways of human relations are described.

7 Epoché concerns phenomenological reduction elaborated by Edmund Husserl, who referred to the metaphor of temporarily "taking in brackets" the beliefs and assumptions [11].

8 The significance of space quality in relation to social interactions is analysed by Jan Gehl in a threelevel scale from the necessary activities, through optional to the resulting or social activities [12], p.38].

9 The concept of "gift" is one of the basic concepts in anthropology. In Maurice Godelier's new interpretation, apart from exchange, there is a sphere of gift, not oriented to profit or calculating, which is the foundation of society [13].

10 Among many authors who study the perception of social situations, Erving Goffman's books can be mentioned: Behaviour in Public Spaces [14], The Presentation of Self in Everyday Life [15] in which the rules governing people's behaviours in space and society are analysed.

11 Today, proxemics form the basis of leading practices in public spaces, initiated by researchers such as William Whyte [16] and Jan Gehl. [12]. See also footnote 6. 
a shift in attitude in which primacy has been given to man and his needs. A consistent application of proxemic principles allows for a measurable change in the quality of urban spaces, resulting in their revival. The practice can prove different, and Wrocław spaces are certainly still far from the unrivalled pattern of Copenhagen or several similar cities ${ }^{12}$.

In my analyses of Wrocław public spaces conducted for several years I have adopted a three-level scale of assessment of urban (public) spaces ${ }^{13}$. It reflects the level of their attractiveness (vibrancy) in relation to how they are created and used (practice), and above all, how they are imagined and understood (sense). At the same time, it shows the degree of care for the quality and operation of a space, which translates directly into the ability to attract people. The first level concerns basic issues - aesthetics, order and safety, the second level concerns sophisticated, unique design which makes a place stand out. The third - last level refers to the social value of places, understood not only in the functional dimension including the issue of proper management, but above all in recognising the full involvement of users in creating a place. While the first level is commonly achieved, the second one is rather rare. However, the degree to which the third level is achieved is not very satisfactory. Of course, some spaces (especially the Wrocław Market Square and its surroundings) are crowded but it happens a little bit on its own, thanks to the tourist character of the places.

While analysing Wrocław spaces, I inevitably focused on official spaces located in the central part of the city, hence the assessment mainly refers to them. For several years now, local/neighborhood spaces of other types have also been created in the city ${ }^{14}$, where users have a wider range of possibilities (e.g. in the form of sports activities) ${ }^{15}$. Their local, non-commercial and, above all, accessible and utilitarian status certainly translates into greater identification of residents with these places. However despite public consultations the nature of these spaces in essence is not fundamentally different from those in my considerations. This is because involvement in these projects takes the form of "para-participation"16, without any actual contribution of residents. Moreover, although they respond to specific needs, they approach people instrumentally - by installing only a set of exercise and play equipment. Such places appear as mere islands in a sea of needs, and to a small extent change the whole situation when all the "unnecessary" elements of living space are eliminated from residential areas ${ }^{17}$.

The results achieved in Copenhagen set the direction to follow, while spaces realized there show a particular broader goal as an achievable one. However, seen from the perspective of a (semi-)provincial city, these goals seem to be very distant. This is where the first doubt arises, since it is not possible to implement them in all conditions. The problem is not the methods themselves but a schematic way of applying them, as it does not include a thorough analysis of the place, let alone a reliable public consultation ${ }^{18}$. The

12 Undoubtedly, Copenhagen leads the way here, developing the strategy Metropolis for people: more people to walk more [17].

13 The research has been described in the text analysing quality of public space in Wrocław[18].

14 Mainly based on the so-called "civic budget" [19].

15 The presence of sports equipment was analysed in a study of beach bars in Wrocław [20].

16 The limited scope of participation, carried out in a simplified fast (voting) mode and appropriated for propaganda and marketing purposes, should rather be called "para-participation" [21].

17 The housing development model, in full acceptance by the city authorities, in less than thirty years completely changed the way of indwelling that was still functioning in the 1980s [22].

18 There are no real bottom-up methods in Wrocław, and decisions are made within the so-called "civic budget" - projects submitted by different actors, sometimes only by "civic" names. However, the consultation is veryformalised in procedural terms [23]. 
second is based on the experience gained from observing beach bars. It shows that even a perfect (if possible) stimulation (organisation/animation) is not sufficient to achieve/ feel something in common - to obtain value for everyone. While beach bars do a lot in this respect, urban spaces by focusing on form and aesthetics are functionally left to the so-called "marketplace action", with an exception of a few events. Once implemented from the top-down, they only change as a result of business adaptation, rarely as a result of bottom-up social interventions ${ }^{19}$.

These two doubts raise a number of questions, particularly in the current political and social context, as to whether the path to perfection (in shaping the city space) is the right and necessary one. Is this what we need? Is catching up, adopting the same priorities, implementing the right policies, allocating the relevant, even higher resources enough to achieve the desired purpose? Well, do we really know what the purpose is? Do we even know where we are heading? Do we know what type/shape of city and its space this way leads to? What spaces do we build and what do they give to users (and indirectly to the city itself and its inhabitants)? What is it, what should be the overriding value? Do we notice this value and its essence? ${ }^{20}$ These purposely exaggerated questions enable to see the issue from a different angle. They come down to explaining/understanding the contemporary role of these spaces and thus are questions about the meaning of what we call ,public spaces”. In other words, what is their meaning to people and especially what we gain by using them, but also why they are sometimes not interesting enough to people.

\section{Similarities and differences}

As a decision to go out in many cases is triggered by a primary social need to be with others and participate in something larger (among people), most choices focus on places that provide conditions for such a meeting to happen. However, today these decisions can also be greatly influenced by other, very different reasons, such as the need for something new, a desire to change the place, a search for different impressions, a direct experience ${ }^{21}$.

The example of beach bars used as mirrors of public spaces, (also used to the beach bars themselves), highlights three important issues about the similarities and differences of contemporary public spaces. Firstly, spaces with a wide, attractive offer are inevitably standardized, where all needs are equated to a "typical" range of services. It limits subjectively perceived attractiveness of these places and thus their full social accessibility, while dissatisfied users (e.g. young people) look for other places more suited to their needs. Secondly, urban spaces, with few exceptions, whether public or pragmatically (private), are created and managed top-down. The former ones by professionals, the latter by owners, which leads to the conclusion that

19 The changes include mainly the change of functions, mostly catering establishments and their operation, e.g. tents in restaurant gardens [24]. One of the most important, otherwise controversial interventions was the one concerning the floor in the Market Square, the so-called "high-hills-way" [25].

20 Such valuation, which increases the attractiveness of the city, may at the same time cause unfavorable processes such as gentrification, leading to, among other things, pushing poor people out of renovated districts, e.g. Copenhagen - the leader in creating public spaces, thus falling to the sixth place in the Global Liveability ranking [26].

21 Most texts concerning public spaces emphasize their affirmative role for the community of the city [27], its socio-political significance [28], or treating human needs only as manifested behaviours [29], paying little attention to the internal, personal needs of people, resulting from psychological conditions, which I will address in the final part of the text. 
they do not belong to the users - they do not belong to the inhabitants of the city ${ }^{22}$. Wherever we go, regardless of the subjective feeling, we are always just guests in the city - we do not feel at home. Thirdly, the three levels of assessment of a space mentioned in the introduction show that its attractiveness is largely dependent on the type of offer, size and possible diversity, as well as aesthetics, design, etc., which also serve well in attracting attention. However, we need to be aware that it is very difficult to achieve a level of attractiveness similar to places that are animated on a regular basis, so to say in a continuous 24/7 cycle (like beach bars), skilful management determines the vitality, spontaneity and dynamics of these places, which for understandable reasons is not available to all spaces ${ }^{23}$.

The obvious differences between these spaces result not so much from their form or character, but rather from their formula - from the way they work, which translates into various possibilities of staying and spending time there. Differences manifest themselves in a close relationship between the manager and the space, in individual animation (in activating/ dynamizing and reviving), allowing for easier and more efficient response to needs and constant adaptation to new requirements (at least theoretically). In this field, beach bar spaces (other new typologies of urban space and similar to them) ${ }^{24}$ bring something new in relation to urban public spaces. Apart from typological otherness (formula/action), their immanent feature is temporariness - an ephemeral, uncertain status of the place. This gives an advantage, which apart from the possibility of quick changes and adjustments to visitors' needs lies in the undeniable freedom of the place that releases greater freedom of user behaviour ${ }^{25}$. This aspect seems to be important not only for meeting the needs better, but also, in my opinion it is also crucial to explain their success, as it promises much more - promises an unconventional, unlimited, full experience, inaccessible in other places ${ }^{26}$. However, for some reasons - mainly because they are essentially no different from the general scheme of operation, they just bite the status quo of existing paralysis and inertia.

\section{Consumption / narration}

The main example of this status quo in Wrocław is the historical Market Square - a meeting place (the city lounge) with a representative, touristic character. The basic offer is provided by numerous restaurants and bars, whose gardens encourage people to spend time in them.

22 The issue of the possession, or rather expropriation of urban residents from space is the subject of in-depth research by many authors, ranging from Henri Lefebvre to David Harvey and Manuel Castells. KacperPobłocki presents and explains this issue in a comprehensive way [30].

23 Beach bars, as private spaces, function similarly to restaurants, as well as efficiently managed undertakings. Their outcome and economic success depend on the way they are run and animated. In the public spaces managed by the city (or its companies) as a whole (cleanliness, security), there is no personal responsibility, only individual events are animated [31].

24 The specificity of beach bars located on the outskirts resembles informal or semi-formal spaces in which unwanted/unallowed activities appear. At the same time, contemporary urban spaces often include various facilities for sports and other activities in their programmes. In my research I analysedSłodowa Island [32, p.103], and Politechnika Boulevard [31], which are such spaces.

25 I analyse this issue in a text comparing beach bars and other urban spaces [31].

26 First of all, the lack of territorial limitations, the possibility of free behaviour, which goes hand in hand with the feeling of homeness/familiarness, which for Michel de Certau is in opposition to geometric space, practiced in a ,joyful and hidden experience” (from childhood) - i.e. „,being different and going through" [33, p.110]. Zygmunt Bauman, on the other hand, by showing how the aestheticization and order of space, in the name of controlling, destroys what is "familiar" and understandable, sees it in opposition to control [34, p.8]. 
Apart from this offer there are no other options for staying as cultural events are organized sporadically ${ }^{27}$. Despite the undoubted attractiveness and popularity, the Market Square space is not inclusive to a large extent - full participation can only take place on a commercial and mercantile level, which undoubtedly affects the feeling of strangeness in those who cannot afford it.

In principle, what this space offers in creating options to stop and encourage social contact (arousing social value) is constructed correctly. The problem lies in lack of diversity and above all openness. The range of possible activities (actions) in official public spaces is limited (a separate question is whether it has not always been like that) to typical "bourgeois", nowadays "tourist" ways of spending time. Against this background, only "excesses" seem to be exceptional: drunken chanting, brawls, less frequently happenings, etc. Bar owners do much more-commercial functions are combined with opportunities for other activities (sports, recreation, culture) and events are animated on a continuous basis.

In urban spaces there is a clear focus on aesthetics and order, which determine the achievement of commercial goals, but at the same time reduce the sphere of freedom of behaviour. The way a contemporary space works (along with users' attitude) focuses on experiences and is largely based on limited consumption patterns ${ }^{28}$, which is wrapped in various stories depicting fulfilment of dreams or just expectations. The prevailing narrative revolves around meeting and the joy of being together, the pleasure of having a meal together, feasting, playing and talking. Consumption drives the vast majority of contemporary public spaces ${ }^{29}$ which base their activity scenarios on it, and this makes this narrative so successful. Yet the widespread use of this story reveals an unfavourable side that can be found in the "flattening" of the offer. It is not even the story itself that is to blame but its realization in many repetitive solutions schemes ${ }^{30}$ which virtually limit possibilities of other choice and in a way impoverish the space itself ${ }^{31}$.

For this reason, space has become a product, by definition ready, finished and offered by whoever is its manager/owner, while users come to a "ready-made" place - they are guests there. They do not build or create anything, they do not share it, and they only use what is offered, given and delivered. People's activity in the space can at most fit into a given framework of a staged offer, allowing only a small degree of choice - our own, independent decisions ${ }^{32}$.

27 E.g. the Market Square is mainly a place for one-off events related to holidays or cyclical events. There are no daily events, only fairs St. John's which last for several weeks make this place more attractive for longer. However, it is difficult to consider it a good solution for the residents [...].

28 The importance of "direct experience" in today's postmodern world is emphasized by Jacek Dukaj $[27$, p.186]. About the search for "uncommon", the need and desire to "carnivalize and color everyday life"writes Rafał Drozdowski [37, p. 296-298].

29 I especially mean Polish public spaces, which live mainly thanks to food facilities. As the BNP Paribas Real Estate report from 2014 shows, there are practically no shopping streets in Wrocław [38].

30 I am referring to the flattening of the offer, progressing under the influence of the global character of the commercialization of space (including the tourism industry), which acts as a limiting factor - we make choices that are "easy" and the story is treated as a soft cushion on which we fall [39, p.22].

31 Our choices, as Marcin Napiórkowski put it, are governed by cultural patterns formed in the "dominant circulation of goods and images", which become common and, consequently, cause the displacement of local, rare and sophisticated niche services [40, p.17]. This dependence is also visible in beach bars, which (with a few exceptions) are becoming more and more similar to each other.

32 Own, independent decisions, and thus the so-called the freedom of choice for the reasons I wrote above, but also above all, in the light of the latest research investigating the (psychological) causes of human action, is highly questionable - this is perfectly illustrated by the research of Daniel Kanneman [41]. 
Such decisions first require an act of self-determination, as without it there is no real choice. This is problematic, because by choosing comfort people do not have their own opinion, and thus they lose the right to decide what our urban spaces might look like.

\section{Policy / restriction of choice}

Reasons for this situation should be sought more broadly and it has its roots in political and economic conditions. It originates from the feeling of being lost in the world that needs to be re-created over and over again from the very beginning, in which we have lost our sense of reference (coordinates). The difficulty of choosing and deciding what to do in such a situation results from shifting the whole responsibility for inefficiency (or resignation) of the system and disappearance of institutions ${ }^{33}$ to an individual. Economic and social conditions of late capitalism in the neoliberal edition, with all its ties (economic enslavement) and especially pace of life and multiplicity of obligations create a dramatic gap between needs/necessities and possibilities ${ }^{34}$.

And hence, there are consequences for cities and their spaces. In today's reality of intermingling and unclear ownership criteria, and above all similarities between the way cities and corporations operate, all procedures in the "spaces of flow" 35 are alike. They are developed slower than changes and then new needs and challenges arise. There is no flexibility achievable only in small organizations, especially those where someone manages their own property, as well as in grassroots initiatives (but these do not build sustainable systems). Moreover, the network character of decision making is "transparent", i.e. based on cyclicality ${ }^{36}$, which favours random compromises and instrumental solutions that do not satisfy real needs. The specificity of a political system with a short term of office lead to showy actions - large-scale monumental and task-based projects.

In urban spaces, these conditions, stretched between global and local, result in standardization - averaging ("flattening") opportunities. Free choice is reduced to choosing options from a given pre-prepared offer. Without user participation the space is programmed and designed from above, it is static - it is a finished object ${ }^{37}$. For this reason, the room for manoeuvre for each of us in relation to public space is becoming limited. On the one hand, urban policy generally aims at mass accessibility of urban spaces (number of people, amount of goods, offer), on the other hand, participation in public spaces does not include everything that is not within "normality", what is individual, what does not accept their "everyday life".

33 Prof. Małgorzata Jacyno spoke about it in an interview with Tomasz Stawiszyński in the programme What is normal, "Philosopher's Hour", 02. 10. 2018 [42].

34 Tomáš Sedláček analyses various levels of economic imbalances, including the issue of the lack of a development limit, against a historical background [43, p.99]. See also footnote 33.

35 In the spaces of flow (the space of power, and today also counter-power), which is the material basis of society, there is a unification of challenges and standards. Being part of the flow space means being part of the context of a huge material infrastructure [44, p.14].

36 Networks are based on the diversity of the parts that make up them, making them more flexible than hierarchical structures. Their identity is determined by internal relations, which make the whole dependent on parts on both sides (John Urry) [45, p.277]. However, their relationships are unstable because they are shaped by continuous adjustment within two-way processes of mutual definition (Castells) [44, p.41].

37 This interpretation is presented by Bruno Latour: the space is not created as in an ex nihilo modernist approach, but rather as a continuous sequence of transformations - an action that means the constant addition of new dimensions [46, p.5]. 
If the possibility of choice - the basis for self-determination is limited or even closed, the question arises, where does today's understanding of public spaces lead us? What is the "for all" strategy all about? What does developing, even scientifically supported, knowledge about human behaviour in space mean when people in this place are reduced to its passive users only? Do we not create a machine-like space ${ }^{38}$ in this way? Are we not forcibly trying to keep, whatever it means, its original "pure" form, whose prototype was the 19th century park? ${ }^{39}$ Or do we have a chance to get out of the impasse of "space-of-using" in favour of "space-of-creating", "space-of-giving", "space-of-cooperating" - common space, our space?

\section{What (public) common space?}

Definitions, and even more postulates towards public space speak about a community place, finding identity, a place in the group, about congruent goals and views ${ }^{40}$. But does a contemporary public space really "strengthen the idea and the feeling that we have something in common?" ${ }^{41}$ or is it just an apparent community? Can we (while being in a public space of the city) speak of a community and a sense of "possessing" (together) something common - not only in the sense of possessing, disposing and being an owner but about the sense of belonging to the group/community that uses the space which it has been given?

In view of tensions of contemporary capitalism, which produces a multitude of those who have no place of their own (has no "anchor") ${ }^{42}$, this common possession becomes extremely important - just as it used to be when first public spaces were created. It balances the lack of private space. However, the time of Olmsted's Central Park - a public space for all, although still a binding model and a point of reference for us, is no longer sufficient and even threatened in face of today's challenges. In this nineteenth-century model (a meeting place for city residents), the common space is neutral and acceptable - everyone can use it ${ }^{43}$. Its non-commercial neutrality determines its strength because it gives a sense of belonging - regardless of the level of possession. However, the conventions and norms of the time were decisive for the sense of unity, the common goal, and they imposed situational rigor but also gave safety (protection) ${ }^{44}$.

38 Such a metaphor of the city has its modernist connotations. Ayssar Arida points out that (modernist) "the machine operates in a finite context, stops time, is an instant creation (it is created from a single shot, immediately) without time for society, without memory" [47, p.111].

39 The nineteenth-century model of space, designed by Frederick Law Olmsted, is a model of today's view on democratic public space, [48].

40 Krzysztof Bierwiaczonek [49] carried out a complementary analysis of this issue. It is also treated by the diagnosis of SARP [50].

41 Tom Nielsen examines such a question on the example of Scandinavian countries [51,p.12].

42 Thomas Piketty analyses the causes of the inequalities and unfair distribution that make up today's financial and economic system [52]. See also footnote 34.

43 Parks were a democratic experiment, they were a safety valve and strengthened the identification of residents, because at the time of their creation they were the only alternative - the clear contrast to urban squares and streets, which mainly functioned as exchange spaces, thus having a different, mercantile character [51, p.3]. Contemporary Wrocław parks only duplicate this model, while new typologies combining parks with various forms of entertainment are developed and work today very well in such implementations as, for example, Superkillen in Copenhagen, project the BIG, TOPOTEK 1 [53] or Park Spoor Noord in Antwerp, project Studio 03 [54].

44 Goffman draws attention to this relationship [15, p.227]. Contemporary conventions in terms of consumer bonding, as analysed by Richard Sennett, have less binding power, which is the result of the desire to express individuality in fear of impersonality [55, p.548]. 
Today, the former conventions and norms give way to regulations, thus the situation without the rigour of social rules turns into a formal one. Thus, contemporary public spaces are not community spaces common to all. Apart from selected fragments of the city, and these are primarily non-commercial spaces - parks, boulevards, squares, this idea is only an echo of that time. We will not find it in contemporary urban spaces, which, in contrast to an "inclusive neutrality" (one community), implement "levelling neutrality" (quantity and not the whole $)^{45}$. These spaces are not spaces for a community, but only a place where individuals gather - where the image of a common space (community) is weakened (and even destroyed) ${ }^{46}$. Images of a common community public space are transferred only in the form of empty clichés referring to historical images of the community. These images are not static, they change fast, even regardless of the scene. As the example of beach bars shows, space users expect something more - they expect a variable, extraordinary experience. And it is not just a matter of commercialization, which rather adapts to expectations generated by invisible (levelling) codes of continuous matching processes ${ }^{47}$. The collective image of community spaces is lame because its matrix is created/born outside of us, as a result of uncontrolled network connections and media influences ${ }^{48}$.

In a world based on a constant search for direct experiences and immediate satisfaction of needs, communities emerge on a different basis - they are temporary just like identities. Individual human molecules - "social atoms" 49 , according to the moment, create different, unstable, social configurations which constantly fluctuate in search of satisfaction. Instead of legible social groups, many different types of patterns - network clusters ${ }^{50}$ are created and quickly disappear. Thus, formal social situations are transformed from homogenous to multifocal ${ }^{51}$.

Simultaneously, we are dealing with a return to tribalism ${ }^{52}$ and retropic nostalgia ${ }^{53}$ that comes with it, trying to stop time in small, closed bubbles to isolate an ideal lost state. Such pursuit is a part of the network layout, but it definitely divides and even conflicts communities

45 Quoting Rossi Braidotti, such communities can be called communities of "nomadic entities" [56, p.16].

46 This is very well identified by Sennett, talking about the "impersonal bonds" of the shapeless narcissistic stress (inability to feel, sense of dissociation, people treat social situations as a reflection of "I" [55, p.501, 522, 527].

47 Contemporary transformation processes, based on the flow-of-space logic, only deepen this interdependence. Castells put it, being a part of the space of flow means belonging into a context of a great material infrastructure [44, p.413].

48 Bauman describes the influence of mass media on an individual's imagination in this way: "Powerful and more real than reality, the images displayed on the ubiquitous screens determine the criteria for evaluating the real world and the directions of repair of the personally experienced world" [57, p.130].

49 Urban communities today are like „free atoms” collectivities (Ulrich Beck) [58], with increasingly weaker, more flexible and fluid ties (Bauman) [57]. They are of network nature (Castells) [44].

50 Such groups/formations are "one of many types of patterns occurring in networks, clusters in a rather scattered, freely connected general network structure of city dwellers" (see Wellman B., Leighton B.) [59].

51 According to Goffman, defined formal situations under the influence of an occasion can move from an overall to a multifocal system, which is a determinant of an informal, casual situation [15, p.232].

52 Michel Maffesoli states that only temporary unity is possible [60, p.190], while Bauman, in turn says about peg communities that arise from hopeless dreams of security in a world in which individuals are already exhausted by uncertainty [61, p.67].

53 Bauman points to a return to the past, which, due to the instability of the present and the uncertainty of the future, appears as the only sure reference for one's own identity that gives the potential to create the present [62]. 
even more. This striving to isolate, find and associate with "one's own" group (de facto to escape from the community of the whole), which results from the network character of contacts and relations ${ }^{54}$ is a power. It collides with the omnipotent integrating and unifying force, which is an inherent power of civilization processes that affects the life in contemporary cities and thus their space ${ }^{55}$.Unnoticeably, in everyday practices, by choosing the same, imposed and culturally produced patterns, taken over without special awareness from the collective imaginary space, the needs are levelled.

Reality is therefore squeezed between two forces: individualization and uniformity. On the one hand, a collection of individuals, separate clients, separate and unique individual needs, on the other hand, there is a levelling "roller" of the same forms and ways of satisfying them. At the same time, the choice was changed into a forced and seemingly independent decision making ${ }^{56}$. In the community of entities - individualities that are an apparent community formed as a sum of various clichés, there is no consensus on a common model of possession (belongings and use). This "non-possession-community" can be seen in various areas, from political to spatial. Urban space accumulates in itself the effects of such a state of affairs, i.e. lack of belonging, awareness, responsibility and (co-)participation. Inevitably, due to no alternative, it is a space replacing the majority (masses) of private space ${ }^{57}$.

\section{Experiences / attractions}

Faced with a clear, inseparable mix of views, ideas and expectations, the public space at the level of the overall community for all (along with the attitude of users themselves) currently focuses on experiences. It becomes and can only be a place (immediately) fulfilling various experiences, various desires - a collection of generally available attractions, follies ${ }^{58}$, a "space of curiosities" ${ }^{\prime 59}$ with a different range of influence. Generality and universality limit - all needs are found there, but not everyone finds themselves in it. Universality requires averaging, flattening the offer, because mass orientation is simpler than maintaining a niche ${ }^{60}$. Choice is possible, but multiplicity and variety is apparent and mainly concerns the "signboard" which nuances the offer in sale strategies In the search present in the mainstream offer which manifests itself in matching, a rich offer and a rapid response to needs coincide with high volatility. In the process of following fashions it makes the offer alike and this flattens it, which also translates

54 "The nature of the objects that make up the network can be very different. They can be human individuals, but also various social wholes: small groups, families, clans, territorial communities, organizations" (Sozański T.) [63, p.28].

55 The process of unification throughout history and from today's perspective is presented e.g. by Yuval Noah Harari [64, p.39], and in statistical terms by Steven Pinker [65].

56 This state of affairs in which, instead of having more freedom, we are more fearful and helpless, the Slovenian philosopher Renata Salecl calls the tyranny of choice [54].

57 Rafał Drozdowski points out as the reason "insufficient quality of private spaces and their inability to perform the originally assigned tasks" [37, p.302]. See also footnotes 46 and 47.

58 Follies (madness, craziness, stupidity) - a name adopted for various types of objects, installation pavilions in public space, based on the project of the park de la Villette, designed by Bernard Tschumi [67]. They are an architectural interpretation of the more open idea of space, "events", "sudden configuration", "unpredictable other", suggested by Jacques Derrida [68, p.65].

59 I borrow the metaphor for "space of curiosities" from the title of Günther Vogt's book Landscape as a Cabinet of Curiosities, which illustrates an approach characterized by offering in the space as many choices as possible - attractions [69].

60 The erosion of public space and urban life is very well identified by Jeffrey Hou in (Not) your everyday public space $[70, \mathrm{p} .6]$. 
into the quality of space and lack of individual character. A different, attracting instantaneity transforms into the same, boring stability (monotony) ${ }^{61}$.

In places located (or which attempt to be located) outside the main mass offer, in the temporary (like a beach bar), a unique atmosphere prevails, which allows moving into a completely different unique world and space. In selecting other, unusual places, one can clearly see an attempt to match one's habitus with another field - a field caught up in the symbolic and imaginary sphere. In this choice, this natural aspiration to change one's position is related to the patterns transferred by culture ${ }^{62}$. For the most part users are interested only in their part of the cake - the curiosities. Individual differentiation serves to attract more attention ${ }^{63}$ (in special cases, a group of "connoisseurs" - the elite able to notice it) and is effective in so far as it ensures a particular "otherness" and at the same time allows to achieve and even multiply (commercial) success. Some selected elements of these other different/distinctive locations, recognized as attractive in the initial period are sucked in a competitive race ${ }^{64}$ and included in the general offer palette, thus losing their special character. Distinguishing (isolating a field) and levelling (gaining a field) is a continuous process, continuously introducing new values and eliminating differences. Certainly, nuancing space loses out to the shock-based surprise and seeking the "wow" effect, while places on the edges are only able to imitate these patterns, yet they always lag behind.

Beach bars (like other, commercially created places for spending time and entertainment) show both individualization and uniformity. They align with prevailing attracting methods and simultaneously stand out from them, for a short time though, because newly emerging beach bars and subsequent seasons blur these differences ${ }^{65}$.

\section{Giving up / enclaves}

This strive to changing position is connected to another side of this movement "pursuit" (after field) - resignation from the "system", giving up what is offered by the top-down proposed official spaces where choices are limited and pauperised. One way of doing this is an "escape upwards" - to enclosed places of private/group luxury. Isolated from the masses, the enclaves lie outside the commonly accessible spaces. They however produce a certain image, a need-challenge responded by the aspiring part of society. Living (being) in these places omnitopiasfor the chosen ${ }^{66}$ ones who can afford it, de facto means being locked in a bubble.

${ }^{61}$ Drozdowski claims that the dominant mainstream culture is subject to constant reproduction, absorbing alternative, extravagant ones, which quickly become tamed (tame) and is soon replaced by more "novelties" [37,p.336].

62 According to Pierre Bourdieu, meaning is found in the common symbolic field that constitutes the group as a whole, dominated by the leading discourse that sets out certain binding social, representative, aesthetic and pragmatic models. The right to control the field and the right to control the discourse, and thus to give the way of its reading, are still in play/fight [71, p.285].

63 An example of such an approach are expressive, iconic architectural forms such as the Metropol Parasol on the plaza de la Encarnación in Seville designed by Jürgen Hermann Mayer [72].

64 Contemporary public space is perceived mainly by its success, measured by its attractiveness (commercial and marketing, usability), reduced to proven factors and good solutions [73].

65 In the 2019 season, I noticed that some beach bars have become similar in their offer and especially in their arrangement, which has become more orderly, even more rigorous, like a restaurant garden [20].

66 Omnitopia "enacts a structural and perceptual enclave whose apparently distinct locales convey inhabitants to a singular place". "When you can flow from place to place, experiencing it all as one vast interior, cocooned in your own bubble, interacting with other people and natural parts of the world only as a series of objects, you're in omnitopia" [74]. 
The second way of giving up participation in official spaces is an "escape down", not so much abandoning the mass offer, as trying to avoid it - searching for an own space (form). In this "escape", places similar to refuges are sought, where the access is not limited only for the "chosen" ones. These may be places with a specific, prepared offer, which is so special that they require, let's call it, courage to go beyond the mainstream and the generally accepted. And beach bars are a good example here (at least some - individually created ${ }^{67}$ ). Another option for giving up are places which enable satisfying one's own specific, unique and exceptional needs - experiences developed, "invented" and prepared by oneself.

Beach bars try to be these both types of escape from the system - they are elite yet widely available. They are part of urban spaces, while being on their margins. they are popular, they are willingly chosen because of their undoubted attractiveness and opportunities for apparent escape. Instead, the idea of refuge of a commercial character is ambivalent. The owners of beach bars can create an atmosphere of freedom, or rather imitate it (their arrangement imitates a distant, exotic place) however, by necessity, the immersion in them takes place rather in the symbolic and/or psychological sphere, and it only works in reference to images generated in this sphere and ends there ${ }^{68}$.

For beach bars work similarly to other spaces ${ }^{69}$ - they strive not to be overtaken in the competitive race by coping/adding what has proven successful in others. Although they offer some form of distinctive individualization (and that includes desired reading, familiarization and acceptance by individual users) it does not seem to bring any long-term benefits - only temporary gains are possible. Thus, as a rule, they do not stand out from other spaces/places (sometimes they do not even differ among themselves) and unique places with a climate are the absolute exceptions ${ }^{70}$.

A more literal example of enclave ("escape") used to be and to some extent still is Słodowa Island ${ }^{71}$ - an informal/semi-formal meeting place for young people. Separated by water, the island's park space allows for free, even extreme behaviour, virtually without control. The lack of rigour (norms) of official spaces is associated with "inconveniences", but these turn out to be an advantage here - the lack of organisation allows for a free choice of places to stay/seat, a constant change of group configuration and a modest food offer for cheap private consumption. There is a clear desire to look for separate, independent places, where the pursuit of certain user groups (mainly young people) to find separated, independent places is clearly visible, where life runs in a different mode, which includes enclaves of

67 E.g. The beach bar "Forma płynna" ("Liquid form") is located in a wild grove where hammocks are spread between the trees [20].

68 The scale and form of these places is also important here - small places, especially those with less formalised arrangements, undoubtedly allow for a more relaxed, almost holiday-like atmosphere [31].

69 I showed it in a text on comparison of beach bars and other (official) urban spaces [31].

70 The whole history of beach bars in Wrocław shows constant levelling and ordering, elimination of "disorder", in which their new forms, using the initial freshness of the idea and symbolic capital, strive to maximise profit by turning these places into "recreation and holiday combinations", exceptions include "Forma płynna" small beach bars at Paderewskiego Street at Opatowicki Bridge and Trzebnicki Bridge [20].

71 Słodowa Island, functioning since 2009 for some time as a liberated, living place for informal meetings (mainly for young people). In 2013 its accessibility has been reduced (the island is closed for the night, this place is also subject to greater control) and the planned private investments (Concordia $H u b$ building [75]) show the strengthening of the formal, controlled order, which threatens to reduce the free, spontaneous character of the island. 
a different type - heterotopias ${ }^{72}$. The conceptual framework of such places is blurred, but this concept of space outside the generally applicable "system" of official spaces and its practices, is possible only for certain places, demarcated for this purpose only. Therefore, it is not so much a bubble of a spatial enclave, inaccessible to other levels of society, but a niche space - an informal space outside official city spaces. It may be unwanted by the system (perhaps even unacceptable), but for some reasons of disinterest it is still temporarily accepted by it. Alternative spaces ("spaces-of-resistance") will be discussed in the next article, which will be the second part of my considerations.

\section{Summary / conclusions}

While in contrast to urban spaces beach bars mark themselves with a slightly different formula (program/action), by placing their proposal in a (seemingly) different narrative they refer only to patterns (imagery) promising specific experiences. This promise (something new) is assigned, admittedly, to all kinds of space, because it is differentiated only by an intangible, relative character of experiences. What is different, however, temporarily extended by a new, fantastic, imaginative (imagined) value, is always more valued - it has a greater charm of attraction $^{73}$. The promise is momentary and therefore very uncertain. It does not add anything when referred to the possibility of creating something shared. On the contrary, because it accentuates what is "distant" (isolated), it causes a greater fragmentation/distortion of the unifying status/character of public spaces.

The example of beach bars in Wrocław seems extremely instructive, and the lesson resulting from analysis of their operation can be beneficial. Against a backdrop of urban spaces, beach bars do not seem to be a completely new/different value - they are rather a splinter from the current, static model, which has become a scheme missing some important tasks/goals. However, the reflection of official public spaces in the mirror of beach bars allows to see them in a wider context in terms of their meaning and possibilities. Moreover, their possibilities, as the above text shows, are limited, mainly because of the unified, "flattened" way they operate and offer.

All forms of (official) public spaces offer a choice, spanning between conforming and resignation ("escape up/down"). The first choice - the most common (mass) is a passive, indifferent acceptance of top-down proposed spaces, the second is a resignation from participation in their offer. All attempts of "escape" are illusory, because they take place in a closed circle of processes/mechanisms, based on commercial/network (and thus anonymous and non-controllable) dependencies. Within these processes, each novelty/individuality, after being tested, is absorbed into a unified offer - a "sack" of various attractions spilled out in the "space-object". The "space-of-curiosities" is a "space-of-use" - a space of self-oriented individuals (and/or ephemeral temporary communities), and not communities (as a whole). As for the majority a public space has become a substitute for a private space, social and situational security, previously provided by old norms and conventions, is currently governed mainly by forms of consumption. However, the "flattened" offer hardly takes into account the diversity of human expression.

72 According to Michel Foucault, heterotopia is a "place-opposition", a kind of utopia in which all the other real places found in culture are simultaneously represented, condensed and reversed. They signify ambiguity, bringing about both desirable and undesirable effects at the same time. This alone can be a deterrent in times when certainty is valued [76, p.24].

73 The space of a contemporary city is that of a spectacle [77], and even more so, simulations that hide something, signs that camouflage the fact that "nothing exists". [78, p.130]. 
Within this context, the answer to the question posed in the introduction about purposefulness of expert/top-down creation of public spaces appears to be somewhat problematic. Of course, this is not about denying the idea of a "city for people" 74 and certainly not those good practices in which empathy towards people is more important than the project itself ${ }^{75}$. However, this top-down approach, seen in reference to a broader context (political, economic and social), raises doubts as to whether the "more and better" strategy is the appropriate one. Politics focuses on creating places, but in isolation from other essential values and rights ${ }^{76}$. Public spaces, even those of good/perfect quality, appear to be "toys for good children", while people are treated instrumentally or in the best case indifferently - the space (and its setting) is in the foreground, not the users. In view to the disappearance of institutions responsible for socio-economic security and a whole range of existential problems of modern man, the policy of "beautifying the city"77 is, despite its many benefits, at least not enough, not to say empty. Especially when proxemic rules are applied in a superficial and schematic way, only to obtain a specific image - when urban space is more of an "image" than a living space for everyone.

Common (public) space, such as the Market Square in Wrocław, is a kind of metaphor that connects the meeting place with consumer attractions. As in the internet world, threats are not directly visible. Gaining some comfort, we agree to gradual (invisible) limitations (this can be called 'enslavement'), which refer to our ability of self-realisation. Meetings with friends over coffee or beer are an attractive form of spending time, but it is actually the only dominant form, we are dealing with some "flattening", which results in the lack of choice, limits experience (and language). And this has wider social consequences.

The main observation that comes to mind is the unquestionable fact of instrumentalization of city dwellers - lack of empathy. Public spaces in today's reality are an "object" ("product"), maybe an excellent one, but only a (systemic) product only indirectly aimed at user-inhabitants. Of course, this does not exclude pride (dignity) and a sense of belonging to the city community (possession), as well as benefits and joy of using these places. However, those who buy and not "other" citizens (especially elder people, who are not present in public spaces in Wrocław) are only welcome. Such a model of space and policy towards them leads to (civil) incapacitation and reinforces the lack of conscious involvement from space users - the prevailing absence of real ownership, the lack of belonging and efficiency, and this feeling is best noticeable especially in young people who are looking for other options ${ }^{78}$.

The next text will examine possibilities that are hidden in places such as Słodowa Island and other similar informal spaces of all kinds of bottom-up attempts to escape from the system ${ }^{79}$ - experiments testing new forms and literally being in a space. Considerations will concern

74 This is the name of the Copenhagen strategy [17] - see footnote 12.

75 This approach can be found, for example, in Project for Public Space (PPS) practice, where people and their needs are put above design and aesthetic values [2, p.40].

76 Ultraliberal politics leaves contemporary man completely alone with the fundamental problems of life, eliminating the right to housing, health care, education and leisure. Bourdieu already pointed out the negative effects of this policy in the 1990s [80].

77 Aestheticization is the leading tactic (literally!) of creating public spaces in Wrocław and other Polish cities [18].

78 Alain Touraine indicates that the logic of capitalism and rationality of the free market destroys the subjectivity and agency of actors, who have no other way of "externalizing themselves in any specific way" [81, p. 79].

79 According to SłavojŻiżek the term "spaces-of-resistance" refers to places, various forms of struggle for rights open to new opportunities, a new future. [81, p.278]. 
whether they serve only the interested parties or whether they also have a potential to create the (real) so-called "space-of-creation", "space-of-giving" and a "space-of-cooperation".

\section{References}

[1] Wismayer H., How London Became a Playground for the Rich. Available: https://medium.com/s/ story/london-doesnt-love-us-b6606af4aef8 [Access: 12 Oct 2019]

[2] PPS, Inc., Jak przetworzyć miejsce. Podręcznik kreowania udanych przestrzeni publicznych, Project for Public Spaces Inc., Wydanie polskie Fundacja Partnerstwo dla Środowiska. Kraków 2009.

[3] Sulima R., Antropologia codzienności. Wydawnictwo Uniwersytetu Jagiellońskiego, Kraków 2000.

[4] Burszta W.J., Antropologia Kultury. Tematy, teorie, interpretacje. Wydawnictwo Zysk i S-ka, Poznań 1998

[5] Stavrides S., "Common Space: the City as Commons".An Atlas of Commoning. Places of Collective Production, ARCH+ Journal for Architecture and Urbanism, ARCH+ Verlag GmbH, Berlin 2018, p.14-19.

[6] Bierwiaczonek K., "Miejskie przestrzenie publiczne i ich społeczne znaczenia - próba", Przegląd Socjologiczny, vol. LXVII (67), 2018, p.25-48.

[7] TUP, Karta Przestrzeni Publicznej. Poznań, 4-5.IX.2009 r. Available: http://www.tup.org.pl/ download/KartaPrzestrzeniPublicznej.pdf [Access: 16 Mar 2015]

[8] Stavrides S., Common Space. The City as Commons. Zed Books, London 2016.

[9] Hall E.T., Bezgłośny język. Państwowy Instytut Wydawniczy, Warszawa 1987.

[10] Hall E.T., Ukryty wymiar. Muza, Warszawa 1997.

[11] Groenewald T., "A Phenomenological Research Design Illustrated", International Journal of Qualitative Methods, vol. 3 (1), 2004, pp. 42-55. Available: https://journals.library.ualberta.ca/ ijqm/index.php/IJQM/issue/view/370 [Access: 25 Nov 2019]

[12] Gehl J., Life between the buildings. VRN, New York 1987.

[13] Godelier M., Zagadka daru. Wydawnictwo Uniwersytetu Jagiellońskiego, Kraków 2010.

[14] Goffman E., Zachowanie w miejscach publicznych. Wydawnictwo Naukowe PWN, Warszawa 2012.

[15] Goffman E., Człowiek w teatrze życia codziennego. Wydawnictwo Altheia, Warszawa 2008.

[16] Whyte W., The Social Life Of Small Urban Spaces. 1980 Project for Public Spaces Inc., New York 1980.

[17] City of Copenhagen, Metropolis for people: more people to walk more. Copenhagen 2009. Available: https://kk.sites.itera.dk/apps/kk_pub2/pdf/646_mIr0dQ6Wdu.pdf [Access: 04.04.2015]

[18] Dziubiński D., "Jakość przestrzeni publicznej Wrocławia”, in Przestrzeń publiczna Wrocławia, Dziubiński D., Rumińska A. (eds.), Oficyna Wydawnicza Politechniki Wrocławskiej, Wrocław 2016, pp. 87-104

[19] Wroclaw.pl, Wroctawski Budzet Obywatelski. Available: https://www.wroclaw.pl/rozmawia/ wroclawski-budzet-obywatelski [Access: 15 Sep 2019]

[20] Dziubiński D., "Beach bars in Wrocław. Space evaluation”, Architectus, no. 4(6), 2019, pp. 93-110. https://doi.org/10.37190/arc190407

[21] Miessen M., Koszmar partycypacji. Fundacja Nowej Kultury Bęc Zmiana, Warszawa 2013.

[22] Happach M., Happach M., "Mieszkaniowy biznes - o warszawskich mieszkaniach XXI wieku”, in Coś, które nadchodzi.Architektura XXI wieku, Świątkowska B. ed. (red. ed.), Fundacja Bęc Zmiana, Warszawa 2011, p. 302-310.

[23] Gazeta Wrocławska, Wrocław rozmawia ale czy stucha swoich mieszkańców. Oto co daja konsultacje spoleczne. Available: https://gazetawroclawska.pl/wroclaw-rozmawia-ale-czy-slucha-swoichmieszkancow-oto-co-daja-konsultacje-spoleczne/ar/12888090 [Access: 12 Jan 2020] 
[24] Tu Wrocław, Ogródki gastronomiczne wedlug nowych zasad. Available: https://www.tuwroclaw. com/wiadomosci,ogrodki-gastronomiczne-wedlug-nowych-zasad-przepisy-wejda-w-zycie-za-cztery-lata,wia5-3273-52155.html [Access: 12 Jan 2020]

[25] Tu Wrocław, Szpilkostrada. Available: https://www.tuwroclaw.com/tag,szpilkostrada,tag4-36256. html [Access: 12 Jan 2020]

[26] Arch Daily,The Most Livable Cities. Available: https://www.archdaily.com/914233/these-are-the20-most-livable-cities-in-the-world-in-2019 [Access: 15 Jan 2020]

[27] Francis J., Giles-Corti B., Wood L., Knuiman M., Creating Sense of Community: The role of public space. Available: https://www.sciencedirect.com/science/article/abs/pii/S0272494412000461 [Access: 15 Oct 2019]

[28] Smith N., Low S., "Introduction: The Imperative of Public Space", in The Politics of Public Space, Smith N., Low S. (eds.), Routledge, Taylor\&Francies Group, New York London 2006.

[29] Daly J., Mahmoudi Farahani L., Hollingsbee T., Ocampo R., "Measuring human experiences of public spaces: A methodology in the making", Conscious Cities Journal, no. 1, 2016.

[30] Pobłocki K., Kapitalizm. Historia krótkiego trwania. Bęc Zmiana, Warszawa 2017.

[31] Dziubiński D., "Beach bars in Wrocław. Private or public spaces?", unpublished manuscript sent to Architektus.

[32] Dziubiński D., "The Odra River Scenarios", in Proceedings of the 50th ISOCARP Congress, pp. 91-108. Available: http://2014.isocarp.org/fileadmin/template/sub_congresses/2014/pdf/ Proceedings_Gdynia_F.pdf [Access: 25 Jul 2019]

[33] deCertau M., Wynaleźć codzienność. Sztuki działania. Wydawnictwo Uniwersytetu Jagiellońskiego, Kraków 2008.

[34] Bauman Z., "O ładzie, który niszczy, i chaosie, który tworzy, czyli o polityce przestrzeni miejskiej”, in Formy estetyzacji przestrzeni publicznej, Wojciechowski J.S., Zeidler-Janiszewska A. (eds.), Instytut Kultury, Warszawa 1998.

[35] SilverMint, Dlaczego nie lubię wrocławskiego Jarmarku? Available: https://www.silvermint.pl/ jarmark-wroclaw/ [Access: 15 Jan 2020]

[36] Dukaj J., Po piśmie. Wydawnictwo Literackie, Kraków 2019.

[37] Drozdowski R., Obraza na obrazy. Strategie społecznego oporu wobec obrazów dominujacych. Wydawnictwo Zysk i s-ka, Poznań 2009.

[38] Knap J., Staniszewska A., Ulice handlowe: analiza, strategia, potencjat. Perspektywy rozwoju ulic handlowych w 8 największych miastach w Polsce. Polska Rada Centrów Handlowych, BNP Paribas Real Estate, Warszawa 2014.

[39] Ingold T., Splatać otwarty świat. Architektura, antropologia, design. Instytut Architektury, Kraków 2018.

[40] Napiórkowski M. Kod kapitalizmu. Jak gwiezdne wojny, Coca-Cola i Leo Messi kieruja twoim życiem. Wydawnictwo Krytyki Politycznej, Warszawa 2019.

[41] Kahneman D., Pułapki myślenia. O myśleniu szybkim i wolnym. Wydawnictwo: Media Rodzina, Poznań 2012.

[42] Stawiszyński T. (prow.), Co to jest normalność, in Godzina filozofów, 02.10.2018. Avialable: https://audycje.tokfm.pl/podcast/67575,Co-to-jest-normalnosc [Access: 25 Oct 2018].

[43] Sedláček T., Ekonomia dobra i zła. W poszukiwaniu istoty ekonomii od Gilgamesza do Wall Street. Wydawnictwo Studio Emka, Warszawa 2012.

[44] Castells M., Społeczeństwo sieci. Wydawnictwo Naukowe PWN, Warszawa 2007.

[45] Urry J., Socjologia mobilności. PWN, Warszawa 2009.

[46] Latour B.A., "Cautious Prometheus? A Few Steps Toward a Philosophy of Design (with Special Attention to Peter Sloterdijk", in Proceedings of the 2008 Annual International Conference of the 
Design History Society, Falmouth, 3-6 September 2009, Hackne F., Glynne J. and Minto V. (eds.), Universal Publishers, pp. 2-10. Available: http://www.bruno-latour.fr/node/69 [Access: 07 Feb 2018].

[47] Arida A., Quantum City. Architectural Press, Routledge, New York 2002.

[48] FrederickLawOlmsted.com, Olmsted's Philosophy. Available: http://www.fredericklawolmsted. com/philos.html [Access: 16 Mar 2016].

[49] Bierwiaczonek K., "Miasto jako przestrzeń identyfikacji jego mieszkańców”, Górnoślaskie Studia Socjologiczne. Seria Nowa, no. 7, 2016, pp. 102-116.

[50] Czyżewska E., Czyżewski A., "Jakość polskiej przestrzeni publicznej. Diagnoza", in Przestrzeń życia Polaków,. Czyżewscy E. i A (eds.), SARP, Warszawa 2014. pp.109-119. Available: http:// www.sarp.org.pl/pliki/1908_53fdc64bb3140-pzp_spistresci_1.pdf. [Access: 16 Mar 2015].

[51] Nielsen T., "Democratic Urban Spaces in the Nordic Countries?", in The Democratic Public Sphere - Challenges and DevelopmentalPerspectives, Working papers, AU IDEAS Pilot Centre No. 4, 2013. Available: http://offentlighed.au.dk/fileadmin/Offentlighed.au.dk/Arb.papir_4.pdf [Access: 16 Mar 2015]

[52] Piketty T., Kapitat w XXI wieku. Wydawnictwo Krytyka Polityczna, Warszawa 2015.

[53] BIG, Superkilen. Available: https://www.architectmagazine.com/project-gallery/superkilen-1304 [Access: 08 May 2019]

[54] Studio 03, Park Spoor Noord. Available: http://www.secchi-vigano.eu/atS03/at\%20S03_park\%20 spoor\%20noord.html [Access: 08 May 2019]

[55] Sennett R. Upadek człowieka publicznego. Wydawnictwo MUZA SA, Warszawa 2009.

[56] Hańderek J., "Współczesne wspólnoty, współczesne wspólnotowości”, in W stronę wspólnotowości, Barłowski D., Gil J., Muca K., Topolski M., Więcek S. (eds.), Wydawnictwo Uniwersytetu Jagiellońskiego, Kraków 2018.

[57] Bauman Z., Płynna nowoczesność. Wydawnictwo Literackie, Kraków 2006.

[58] Beck U., Spoleczeństwo ryzyka. W drodze do innej nowoczesności. Wydawnictwo Naukowe Scholar, Warszawa 2002.

[59] Wellman B., Leighton B., "Networks, Neighborhoods, and Communities: Approaches to the Study of the Community Question",in The Urban Sociology Reader, Lin J., Mele C. (eds.), Routledge, London, New York 2013, p. 58-67.

[60] Maffesoli M., Czas plemion. Schyłek indywidualizmu w społeczeństwach ponowoczesnych. Wydawnictwo Naukowe PWN, Warszawa 2008.

[61] Bauman Z., Etyka ponowoczesna. Warszawa 1996.

[62] Bauman Z., Retropia. Jak rzadzi nami przeszłość?. Wydawnictwo Naukowe PWN, Warszawa 2018

[63] Sozański T., "Sieć społeczna”, in Encyklopedia socjologii PWN, Wydawnictwo Naukowe PWN, Warszawa 2002, p. 28-36.

[64] Harari Y.N., Sapiens. Od zwierząt do bogów. Wydawnictwo PWN, Warszawa 2014.

[65] Pinker S., Nowe oświecenie. Argumenty za rozumem, nauka, humanizmem i postępem. Zysk i S-ka, Poznań 2018.

[66] Salecl R., Tyrania wyboru. Wydawnictwo Krytyki Politycznej, Warszawa 2009.

[67] Tschumi B., Park de la Villette. Avialable: http://www.tschumi.com/projects/3/ [Access: 15 May 2019]

[68] Derrida J., Point de folie - Maintenantl'architecture, AA files No.12 Summer 1986, pp. 65-71.

[69] Vogt G. "Landscape as a Cabinet of Curiosities", in In Search of a Position, Bornhauser R., Kissling T. eds., Lars Müller Publishers, Zürich 2015.

[70] Hou J., "(Not) your everyday public space”, in Insurgent Public Space. Guerrilla urbanism and the remaking of contemporary cities, Jeffrey Hou eds., Routledge Taylor \& Francis, London and New York, 2010. 
[71] Bourdieu P., Dystynkcja, Społeczna krytyka władzy sądzenia. Wydawnictwo Naukowe Scholar, Warszawa 2005.

[72] Mayer K.H., Metropol Parasol. Available: http://www.jmayerh.de/19-0-Metropol-Parasol.html [Access: 15 May 2019]

[73] Gomes P.S., Factors of Good Public Space Use. Available: https://www.academia.edu/2069849/ Factors_of_good_public_space_use [Access: 16 Oct 2019]

[74] Wood A.F., City Ubiquitous: Place, Communication, and the Rise of Omnitopia. Hampton Press, New York 2009.

[75] Gazeta Wrocławska, Concordia Hub. Połaczenie biznesu I inicjatyw społecznych. Available: https://gazetawroclawska.pl/concordia-hub-proba-polaczenia-biznesu-i-inicjatyw-spolecznych-na-wyspie-slodowej/ar/c1-14427407 [Access: 23 Oct 2019].

[76] Foucault M., "Of the Other Spaces: Utopias and Heterotopia”, in Rethinking Architecture: A Reader in Cultural Theory. ed. N. Leach. Routledge, New York 1997, pp.330-336.

[77] Debord G., Społeczeństwo Spektaklu oraz Rozważania o społeczeństwie spektaklu. Państwowy Instytut Wydawniczy, Warszawa 2006.

[78] Baudrillard J., Symulakry i symulacja. Wydawnictwo Sic!, Warszawa 2005.

[79] Wroclaw.pl, Wrocławski Budżet Obywatelski. Available: https://www.wroclaw.pl/rozmawia/ wroclawski-budzet-obywatelski [Access: 15 Sep 2019]

[80] LavalI Ch., "Foucault and Bourdieu: to Each His Own Neoliberalism?", Sociologia\&Antropologia, vol. 7, no.1, Rio de Janeiro Jan./Apr. 2017. http://doi.org/10.1590/2238-38752017v713

[81] Touraine A., Myśleć inaczej. Państwowy Instytut Wydawniczy, Warszawa 2011.

[82] Žižek S., Living in the End of Times. Verso Books, London/New York 2010. 
